\title{
Role of Transformational Leadership on Innovative Pro-poor Development Initiatives in Zanzibar: A Case of Selected Community-based Income Generating Projects in the Urban West Region, Zanzibar
}

\author{
Ayoub Mohammed Mahmoud
}

Open University of Tanzania-Zanzibar Centre, Tanzania

Received November 1, 2019; Revised December 13, 2019; Accepted May 13, 2020

\section{Cite This Paper in the following Citation Styles}

(a): [1] Ayoub Mohammed Mahmoud, "Role of Transformational Leadership on Innovative Pro-poor Development Initiatives in Zanzibar: A Case of Selected Community-based Income Generating Projects in the Urban West Region, Zanzibar," Universal Journal of Management, Vol. 8, No. 6, pp. 285 - 295, 2020. DOI: 10.13189/ujm.2020.080601.

(b): Ayoub Mohammed Mahmoud (2020). Role of Transformational Leadership on Innovative Pro-poor Development Initiatives in Zanzibar: A Case of Selected Community-based Income Generating Projects in the Urban West Region, Zanzibar. Universal Journal of Management, 8(6), 285 - 295. DOI: 10.13189/ujm.2020.080601.

Copyright $\bigcirc 2020$ by authors, all rights reserved. Authors agree that this article remains permanently open access under the terms of the Creative Commons Attribution License 4.0 International License

\begin{abstract}
Leadership style is one of the factors that play a significant role in enhancing or retarding the performance of individuals in any organization. This study attempted to reveal the role of transformational leadership on innovative pro-poor development initiatives in Zanzibar where selected community-based income generating projects in the Urban West Region, Zanzibar were used a case study. Data were collected from six shehias namely Mwera, Kihinani, Kisauni, Kiembesamaki, Matarumbeta and Chumbuni where 180 respondents were consulted through observation, interview and questionnaire methods. Data analysis was done for each study objective through content analysis and descriptive statistics. The study findings revealed 7 major transformational leadership practices in the study area including motivation, periodic appraisals, inspiration, volunteering, mentoring, sharing and training. On the other hand the study concluded 6 major community based income-generating activities namely animal keeping, poultry keeping, vegetable garden, fish processing, small businesses and hand-crafting business. This study further revealed numerous challenges facing the adoption of transformational leadership in various development initiatives in the study area including lack of skills, lack of fund, lack of knowledge, low level of education, poor perception of the community and inadequate awareness of
\end{abstract}

the existing pro-poor projects. Lastly based on the study findings, it was concluded that poultry keeping was highly practiced activity in the study area. Capacity building interventions were highly urged for enhancing skills, knowledge and awareness of the adoption of transformational leadership in various development initiatives in the study area hence making the existing pro-poor initiatives useful in the study area.

Keywords Transformational Leadership, Pro-poor Development Initiatives, Community-based Income Generating Projects

\section{Introduction}

In today's ever growing developments in the business world prevailed by myriad complex scenarios, much have also motivated efforts by practitioners and scholars to identify factors that can stimulate various organizations performance aspects including efficiency and progress in various community development aspects. Among the factors that influence organizational performance, leadership has been widely identified by many researchers as being one of the most important factors (Amabile, 1998 
and Allix, 2000). Leadership is a prominent aspect which has been widely pointed out by researchers since old times. Because of their unique traits, leaders influence the organization and society overall. Effective leadership always plays an important role in the growth and better performance of any form of organization. In the organizations, transformational leaders could be a competitive advantage to increase the efficacy and performance of such organizations (Adair, 1988).

According to Sharma and Jain, (2013) leadership refers to a process by which a person influences others to accomplish an objective and directs the organization in a way that makes it more cohesive and coherent to achieve the course of action. On the other hand Northouse's (2007) defines leadership as a process whereby an individual influences a group of individuals to achieve a common goal. The leadership process involve influencing others willingly to understand and agree about what needs to be done and how to do it, and the process of facilitating individual and collective efforts to accomplish shared objectives. Concurrently to what argued by Gronn, (1996) that leadership at one time in life meant applying muscle to get things done, but in the contemporary times leadership means getting along with people in their own pursuit.

In these modern times leaders carry out leadership process by applying their leadership knowledge, skills and potentials. Leithwood, (1994) defined leaders as people who provide vision and meaning for an institution and embodies the ideals towards which the organization strives. It further opines that good leaders are made not born such you have the desire and willpower, you can become an effective leader through trainings and various capacity building programs. Good leaders develop through a never ending process of self-study, education, training, and experience. A leader must have an honest understanding of who you are, what you know, and what you can do. It is widely argued that it is the followers, not the leader or someone else who determines if the leader is successful. For a leader to be successful you have to convince your followers, not yourself or your superiors, that you are worthy of being followed.

The concept and definition of leadership and style may differ from one place, person or situation, to the other. Previous views about leadership show it as personal ability. Jantzi, (1999) argued that the degree to which the individual exhibits leadership traits depends not only on his characteristics and personal abilities, but also on the characteristics of the situation and environment in which he finds himself. However, leadership is learned, the skills and knowledge processed by the leader can be influenced by his or hers attributes or traits; such as beliefs, values, ethics and character. Historically, leadership has carried the notion of masculinity and the belief that men make better leaders than women is still common today. Although the number of female leaders has increased, they are often named as an afterthought. Burns (1978) identified two types of leadership based on the nature of leader-follower interactions: transactional and transformational.

Transformational leadership is defined as a leadership approach that causes change in individuals and social systems. Transformational style of leadership is a stimulating technique through which a leader can inspire and apply that ability of motivation thinking (Allix, 2000). The key constituents of transformational leadership are: inspirational motivation and idealized influence, which functions as a charismatic paradigm and expresses an image of the future that is communal. Transformational leaders inspire followers to accomplish more by concentrating on the follower's values and helping the follower align these values with the values of the organization. Transformational leadership has been associated with the personal outcomes (Yuki, 1994).

The fact that leadership style in any kind of organization is one of the factors that play significant role in enhancing or retarding the interest and commitment of the individuals in the organization, managers should select transformational leadership more that any form of leadership (Glantz, 2002). However, the extent to which members of an organization contribute in harnessing the resources of the organization equally depends on how well the managers (leaders) of the organization understand and adopt appropriate leadership style in performing their roles as managers and leaders. Since the organizational performance features entail efficiency in resources mobilization, allocation, utilization, hence the enhancement of organizational performance depends, to a large extent, on leadership style, among other factors. Moreover Akpala (1998) identifies attitude to work, leadership style and motivation as some of the factors that widely influence organizational performance.

According to Mahmoud, (2018), in many of developing countries including Zanzibar, the aspect of leadership is highly linked with the ability of the leadership regime to alleviate poverty existing in the population in the given area. The fact that the prevalence of all forms of poverty is still very high in Tanzania, the Household Budget Survey, 2007 (NBS, 2009) posits the proportion of the population below the national food poverty line is $16.6 \%$ with slight decline from $21.6 \%$ in $1991 / 92$ and $18.7 \%$ in $2000 / 01$ (URT, 2010). According to the same source of information, the population below the national basic needs poverty line is $33.6 \%$ and declined from $38.6 \%$ in 1991/92 and $35.7 \%$ in $2000 / 01$. Poverty remains overwhelmingly high in rural areas where $87 \%$ of the poor population lives. According to the Household Budget Survey, 2007 (NBS, 2009), the proportion of the rural population below the national food poverty line is $18.4 \%$ and declined from $20.4 \%$ in $2000 / 01$ and $23.1 \%$ in $1991 / 92$, whereas the proportion of rural population below the basic needs poverty line is $37.6 \%$; it declined from $38.7 \%$ in $2000 / 01$ 
and to $40.8 \%$ in 1991/92. According to 2011/12 Household Budget Survey the basic needs poverty line is 36,482 Tanzanian Shillings per adult equivalent per month and food poverty line is 26,085 Tanzanian Shillings per adult equivalent per month. Using these two poverty lines, more than a quarter (28.2\%) of the Tanzanian population fall below the basic needs poverty line and 9.7 percent falls below the food poverty line. The recent reported improvement in falling basic needs poverty reflect the improved living standards among many communities in Tanzania including Zanzibar (Mahmoud, 2018). In the quest of navigating towards more reliable and innovative initiatives for transforming the existing development challenges in the majority of communities in Zanzibar, various interventions have been designed and put in place.

Despite the widely known challenges, extent and usefulness of transformational leadership towards influencing myriad aspects of organizational development (Maxwell, 2007; Burns, 1978; Glantz, 2002; Obiwuru et al., 2011), less remains to be known on the exactly role played by transformational leadership towards influencing innovative pro-poor development initiatives in Zanzibar. In the view of pursuing this study, innovative pro-poor development initiatives can further be referred to the ability of the community to create and discover various livelihoods options including income generating projects which helps transforming the livelihoods of communities. In view of this study, the usefulness of transformational leadership towards enhancing the existing innovative pro-poor development initiatives can be directly reflected from various livelihoods interventions in the designated area namely selected shehia from three municipality councils from the Urban West Region in Zanzibar where small and medium income generating activities have been taking place as result of transformational leadership practices.

This among other factors poses a rationale of revealing the role of transformational leadership on innovative pro-poor development initiatives in Zanzibar. The recent existing innovative pro-poor development initiatives stand as the responses towards improving the falling basic needs poverty which results to the improved living standards among many communities in Zanzibar. Consequently, the study under question calls for the need of undertaking an empirical study to reveal the actual role of transformational leadership towards discovering and income generating projects which helps transforming the livelihoods of communities which is a reflection of the existence of pro-poor development initiatives in Zanzibar. This study intends to reveal the role of transformational leadership on innovative pro-poor development initiatives in Zanzibar where selected community-based income generating projects in the Urban West Region, Zanzibar were used a case study. This study was set in response to the following specific objectives of the study: i. To examine current available transformational leadership practices in the innovative pro-poor development initiatives in the Urban West Region.

ii. To assess the impacts of transformational leadership on innovative pro-poor development initiatives in the Urban West Region.

iii. To assess the challenges facing the adoption of transformational leadership in various development initiatives in the Urban West Region.

\section{Research Methodology}

\subsection{Study Area and Target Population}

The study was conducted in all of the 6 selected shehias from the three municipalities in the Urban West Region, Zanzibar. The selected area was sought suitable for the study since it is the place where many income generating activities have been taking place recently. Furthermore, the entire scope of Urban West Region area was easily accessible by a researcher due to limited time, cost for the data collection exercise hence the researcher was able to accomplish the data collection exercise on time. The study took place in 6 randomly selected shehias; two from each of three municipalities in the Urban West Region, Zanzibar. The six randomly selected study shehias were meant to bring out the target population sampling units of analysis including all residents including youth, women, business stakeholders, government, religious and community leaders, community members, small-business community leaders and entrepreneurial groups. The six study shehias were randomly selected based on the high prevalence of innovative pro-poor development initiatives including the recently established and practiced small income generating activities by majority communities in the areas as a result of the recent transformational leadership practices.

\subsection{Study Design, Sampling Procedures and Sample Size of the Study}

This study used a descriptive case study research design. Under this design both quantitative and qualitative approaches were applied to explore contemporary real-life scenarios relating to role of transformational leadership on innovative pro-poor development initiatives in Zanzibar. This design managed to engage in-depth data collection methods involving detailed multiple sources of information in relation to reveal the latest state of art practices in the study area (Bryman and Bell, 2011; Creswell, 2013). In the course of obtaining the reliable scientifically justifiable number of respondents to participate in this study as well as attaining heterogeneity of the views, the sample size determination formula adopted from Bartleh et al., (2001) was employed to yield 
the reasonable number of respondents to participate in this study.

The $5 \%$ of all of the total number of the participants from the selected cohorts of touristic related businesses from study area was treated as the total sample size. On the other hand the formula in the Bartleh et al., (2001) recommended a sampling intensity of $5 \%$ of total number of sampling units from the study site. Bartleh et al., (2001) further posits that the study sample size is considered adequate and able to fit statistical analyses if and only if it entails the reasonable proportion of the units from the sampling frame but being not less than 30 units per the selected study cohorts (shehias). For the purpose of this study, a sampling intensity of $5 \%$ was adopted as presented in the Table 1 below. The sample size of this study was equivalent to the total of 180 respondents meaning that 30 respondents were randomly sampled from each of the six shehias as presented in the Table 1 below.

Table 1. Distribution of the study sample size

\begin{tabular}{|l|ll|c|}
\hline \multicolumn{1}{|c|}{$\begin{array}{c}\text { Designated } \\
\text { District }\end{array}$} & \multicolumn{2}{|c|}{$\mathbf{5 \% \text { of Total Number Respondents }}$} & Total \\
\hline West A District & $\begin{array}{l}30 \text { respondents from each of } 2 \\
\text { selected shehias }\end{array}$ & 60 \\
\hline West B District & $\begin{array}{l}30 \text { respondents from each of } 2 \\
\text { selected shehias }\end{array}$ & 60 \\
\hline Town District & $\begin{array}{l}30 \text { respondents from each of } 2 \\
\text { selected shehias }\end{array}$ & 60 \\
\hline Total & $\mathbf{1 8 0}$ \\
\hline
\end{tabular}

\subsection{Data Collection Techniques and Data Analysis Procedures}

The study employed various data collection techniques including questionnaires and interviews during the process of collecting information from the study respondents. Questionnaires technique was used to gather data from all of 180 respondents who were mainly beneficiaries and actors in the income generating projects from the six randomly selected shehias from the study area. On the other hand interview technique including key informants interviews and focus group discussions were used for the key informants including community and government leaders including Shehas (shehia's leaders), Community Development Officers and other religious and entrepreneurial leaders from the study area. Both of qualitative and quantitative approaches were employed in this study for the purpose of having detailed information and making sure triangulation and complementarily is achieved. Lastly the survey and reviews on various literatures were made to supplement the collected primary data on hand.

Furthermore the analysis of data relied much on both quantitative and qualitative data analysis approaches including content analysis, simple percentages, descriptive analysis and explanations to establish relationships of the variables employed in the study. Simple codification was employed to extract relationships and associations among the population variables of the study. The simple qualitative classifications of data, distribution and the measures of dispersions were used in measure of the role of transformational leadership on innovative pro-poor development initiatives in Zanzibar. With the aid of Microsoft Excel and Statistical Package for Social Sciences (SPSS 22.0) computer programs, data analysis for each objective was rigorously performed, results presented and discussed in the sub-sequent sections hereunder.

\section{Results and Discussions}

\subsection{Respondents' Profile}

The fact that Northouse, (2007) defines leadership as a process whereby an individual influences a group of individuals to achieve a common goal, this study has revealed the term leadership as the process involve influencing others willingly to understand, agree and participate on designing what needs to be done and how to do it and the process of facilitating individual and collective efforts to accomplish shared organizational objectives. This study has fit itself in the context of the modern times we are living in, mostly in developing counties including Zanzibar such that the existence of high levels of complexities in our societies, competitions, innovations and various developments in myriad context of community development.

In the course of allocating the useful sample size of this study which could examine the research questions on hand, an equivalent of the total of 180 respondents were randomly sampled from each of the six shehias namely Mwera, Kihinani, Kisauni, Kiembesamaki, Matarumbeta and Chumbuni as presented in the Table 2 below. The fact that two shehias were selected from each of the 3 designated districts from the Urban West Region; meaning that 30 respondents were drawn from all of the selected 6 shehias making a total of 180 respondents to be involved in the study

Table 2. Distribution of the study sample size

\begin{tabular}{|c|c|c|}
\hline Designated District & Selected Shehia & Total \\
\hline \multirow{2}{*}{ West A District } & Mwera & 30 \\
\cline { 2 - 3 } & Kihinani & 30 \\
\hline \multirow{2}{*}{ West B District } & Kisauni & 30 \\
\cline { 2 - 3 } & Kiembesamaki & 30 \\
\hline \multirow{2}{*}{ Town District } & Matarumbeta & 30 \\
\cline { 2 - 3 } & Chumbuni & 30 \\
\hline Total & $\mathbf{6}$ Selected Shehias & $\mathbf{1 8 0}$ \\
\hline
\end{tabular}

Source: Field data (2019)

The drawn earmarked sample size of the respondents who participated in this study from selected shehias were 
such that the 180 respondents who practice the selected community-based income generating projects in the 6 selected shehias from all of the three districts of the Urban West Region, Zanzibar. The widely spread sample size over the wide area is envisaged to contain the best means of harnessing information relating to the role of transformational leadership on innovative pro-poor development initiatives in Zanzibar. On the other hand, it was envisaged that respondents' profile included sex of respondents such that the study findings revealed majority of respondents 114(63.3\%) were male, while 66(36.7\%) were female respondents.

Table 3. Distribution of Sex of Respondents

\begin{tabular}{|c|c|c|}
\hline Sex & Frequency & Percent \\
\hline Female & 66 & 36.7 \\
\hline Male & 114 & 63.3 \\
\hline Total & $\mathbf{1 8 0}$ & $\mathbf{1 0 0 . 0}$ \\
\hline
\end{tabular}

Source: Field data (2019)

Furthermore, the study found an important parameter in the respondents' profile namely the ages of respondents. This stood as an important parameter in bringing light on the segments of participation of male and female respondents in the selected pro-poor projects in the study area such that the study revealed $63.3 \%$ of the entire pool of respondents entailed male respondents. The study findings presented in the Table 3 of $36.7 \%$ female and 63.3\% male respondents imply patriarchy kinship in the study area which mostly reflect African traditions settings where majority of the households follow patriarchy kinship where by men are widely reported to participate in various socio-economic activities in the study area including the income generating activities which were mentioned in the subsequent sections. The sex-structure of the respondents involved in this study represents most of African work-structures which entailed many men respondents in many units and departments in the various social entities.

Table 4. Distribution of the Ages of Respondents

\begin{tabular}{|c|c|c|}
\hline Age groups & Frequency & Percent \\
\hline $41-50$ & 33 & 18.3 \\
\hline $31-40$ & 53 & 29.4 \\
\hline $20-30$ & 89 & 49.5 \\
\hline Below 20 & 5 & 2.8 \\
\hline Total & $\mathbf{1 8 0}$ & $\mathbf{1 0 0 . 0}$ \\
\hline
\end{tabular}

Source: Field data (2019).

Since the study found that majority of respondents in the study area aged within the productive age 20-30 years, the study findings imply the presence of useful workforce in the community. Many authors in the line of pro-poor studies have revealed the same findings such that when majority of respondents fall in the workforce age-group it is evident that every respondent can be a useful participant in revealing the quest of the study on hand. Also this study finding suggests the availability of supportive workforce for effective and sustainable undertaking of pro-poor income generating projects in the study area.

This study finding reflects most the distribution of people in most communities in developing countries such that majority of the members of the existing societies in these modern times compose the steady workforce such that they easily participate in both civic and economic processes. The presence of $49.5 \%$ of all respondents being between 20-30 years and many other respondents being in the active population hence they were envisaged to be useful population in the undertaking of this study such that the participation of the majority of respondents who participate in the questionnaire survey and interview and the entire study undertaking.

\subsection{Currently Available Transformational Leadership Practices in the Innovative Pro-poor Development Initiatives in the Urban West Region}

In the course of attempting to examine the current available transformational leadership practices in the innovative pro-poor development initiatives in the Urban West Region, it was firstly sought to be useful to identify the available transformational leadership practices and the mostly practiced community based income-generating projects in the study area. The unveiled two main attributes of this study were envisaged to be useful in creating the standpoint for the study stand and reveal other useful areas for transformation leadership to work for the mostly practiced community based income-generating projects in the study area.

\subsubsection{The Available Transformational Leadership}

Practices in the Study Area

The study sought to examine the available transformational leadership practices in the study area. The findings presented herein reflect the views of the respondents interviewed during the questionnaire survey. The fact that the issue of leadership is a very important aspect towards organizational performance, transformational leaders are those who generally observe principles of human dignity and worth, human rights, good social values and individual and socio-political transformation; such leaders are able to recognize and enhance existing needs, feelings and demands of potential pools of followers. Transformational leadership which is also closely associated with charismatic form of leadership would however it places heavy emphasis on the concept of a mutually supportive relationship of moral and motivational engagement between the leaders and the led. In the course of revealing existing transformational leadership practices in the study area, the basic existing transformational leadership practices in the study area as presented in the Table below. 
Role of Transformational Leadership on Innovative Pro-poor Development Initiatives in Zanzibar: A

Case of Selected Community-based Income Generating Projects in the Urban West Region, Zanzibar

Table 5. The existing transformational leadership practices in the study area

\begin{tabular}{|c|c|c|c|c|c|c|c|c|}
\hline \multirow{2}{*}{ Practices } & \multicolumn{9}{|c|}{ Responses } \\
\cline { 2 - 10 } & \multicolumn{2}{|c|}{ Not at all } & \multicolumn{2}{|c|}{ Small extent } & \multicolumn{2}{|c|}{ Moderate } & \multicolumn{2}{c|}{ Large extent } \\
\cline { 2 - 10 } & $\mathrm{F}$ & $\%$ & $\mathrm{~F}$ & $\%$ & $\mathrm{~F}$ & $\%$ & $\mathrm{~F}$ & $\%$ \\
\hline Motivation & 12 & $7 \%$ & 22 & $12 \%$ & 44 & $24 \%$ & 102 & $57 \%$ \\
\hline Periodic Appraisals & 19 & $11 \%$ & 29 & $16 \%$ & 40 & $22 \%$ & 92 & $51 \%$ \\
\hline Inspiration & 2 & $1 \%$ & 14 & $8 \%$ & 38 & $21 \%$ & 126 & $70 \%$ \\
\hline Volunteering & 0 & $0 \%$ & 5 & $3 \%$ & 25 & $14 \%$ & 150 & $83 \%$ \\
\hline Mentoring & 3 & $2 \%$ & 5 & $3 \%$ & 20 & $11 \%$ & 152 & $84 \%$ \\
\hline Sharing & 0 & $0 \%$ & 2 & $1 \%$ & 16 & $9 \%$ & 162 & $90 \%$ \\
\hline Training & 1 & $1 \%$ & 7 & $4 \%$ & 32 & $18 \%$ & 140 & $78 \%$ \\
\hline
\end{tabular}

Source: Field data, (2019).

The revealed study findings which are presented in the Table 5 entail transformational leadership practices including motivation, periodic appraisals, inspiration, volunteering, mentoring, sharing and training practices. The namely practices which are widely done by the transformational leaders available in the study area such that people feel more touched by the practices. The revealed practices reflect the situation in the study area such that the existence of motivation by leaders, periodic appraisals and follow-ups of their directives and orders, inspirational speeches and actions, volunteering spirits among leaders and followers, mentoring through various interactions between leaders and people who are led, sharing various moments between leaders and people who are led and lastly was revealed on the training which were provided to people in various times and moments. The findings reflect numerous view points from authors including Gilstrap, (2009), Gieseke and Walter, (1997) and Townley, (1999) that transformational leadership has been proven to continue to rapidly develop organizations to be more responsive to change as it often rely on strategic plans which guide development of organizations to identify and undertake responsive change timely.

On the other hand, transformational leadership is being used to guide the development of pro-active initiatives and to support organizational development and related efforts which are effective in addressing change (Yuki, 1994; Yanmarino, 1998). The revealed practices concur the widely opined fact that leadership involves mobilizing people to get things done. It also involves motivating people and managing resources. In many cases leadership is considered as a reciprocal process between those who aspire to lead and those who choose to follow on any given task(s) and duty(ies). Since there are may be times when one person or group leads and another time when someone else does, leadership comes into subtle the interplay of many factors, including: organizational goals, personal values, individual working preferences, organizational structure and rules. This study revealed transformational leadership practices namely motivation, periodic appraisals, inspiration, volunteering, mentoring, sharing and training hence portraying the existence of transformational leadership towards enhancing organizational outcomes.

Since transformational leadership is the act of getting extraordinary things done; often in extraordinary times; certainly a characteristic of today's situation in Zanzibar and the rest of developing world, Kouzes and Posner (2007) have identified five practices that transformational leaders use to bring extraordinary impact including; firstly modeling the way, secondly inspiring a shared vision, thirdly challenging the process, fourthly enabling others to act and lastly encouraging the heart. The revealed practices may involve the use of structural, human relations, and political techniques found in the other parameters of the development context.

Bryman (1992) within his book has postulated that the transformational leader invariably integrates the concept of charisma within their leadership style, to create a sense of followership/discipleship. Gronn (1996) has also noted the close relationship in many commentaries on leadership between transformational and charismatic leadership; see also Leithwood et al (1999). The transformational charismatic leader described by Bryman (1992) engages in developing a vision of the entire group of the followers in such a way motivational practices prevail widely.

On the other hand periodic appraisals among the workers were revealed to improve the workers' morale from time to time and hence improve organisational performance from time to time. The revealed transformational leadership practices enable and influence others subordinates to practice their daily responsibilities and hence fostering collaboration and strengthening others. Consequently, the study findings reflect the arguments in Kouzes and Posner, (2010) opining that transformational leadership practices reflect the productivity of the members of an enterprise measured in terms of revenue, profit, growth, development and expansion of the organization. The fact that leaders generate enthusiasm and excitement for the common vision from others (Kouzes and Posner, 2002), the art of inspiring and motivating other workers from top leaders exhibiting the 
behaviour they expect from followers by setting example to others also concurring Sharma and Jain, (2013) findings.

Since inspirational practices were revealed by $13.3 \%$ in the study area, the management was reported to engage herself in the various inspirational practices such that all workers are inspired to get involved in various levels of operations to yield the desired outcomes. The findings are in line with the propositions in the transformational theory which suggests that a leader might transform subordinates interest and at the same time motivate his followers or subordinates in order to achieve greater goals and higher productivity in any organization, hence inspiration and training practices are the ones to bring all workers get involved in the organization. The study findings were supplemented by the viewpoints from Odumeru et al., (2013) positing the key constituents of transformational leadership are: inspirational motivation and idealized influence, which functions as a charismatic paradigm and expresses an image of the future that is communal.

\subsubsection{The Mostly Practiced Community Based Income-Generating Projects in the Study Area}

The fact that this study was trying to connect the transformational leadership outcomes in relation to the prevailing community based income-generating projects in the study area, this sought it useful to reveal the mostly practiced community based income-generating projects in the study area. Since transformational leadership emphasizes mostly on the concept of a mutually supportive relationship of moral and motivational engagement between the leaders and the led, the power bases are envisaged to be linked to the course of pursuing common and ever increasing purposes (Allix, 2000). The revealed community based income-generating were possible to be developed by various actors in the study area because of their information collected and the members' openness and willingness to make economic changes for the wide and broad community participation. Through the innovative introduced practices in the study area, the community had an opportunity to change their status of income in their families if they built their skills that could make them overcome the poverty from their own resources and opportunities. This means that the sustainability of introduced community based income-generating activities could guarantee lasting and effective means for poverty alleviation if the majority community members including women and youth could get more knowledge of using their own resources in the community. The study revealed 6 major community based income-generating activities in the study as a result of adoption of transformation leadership practices in the area.

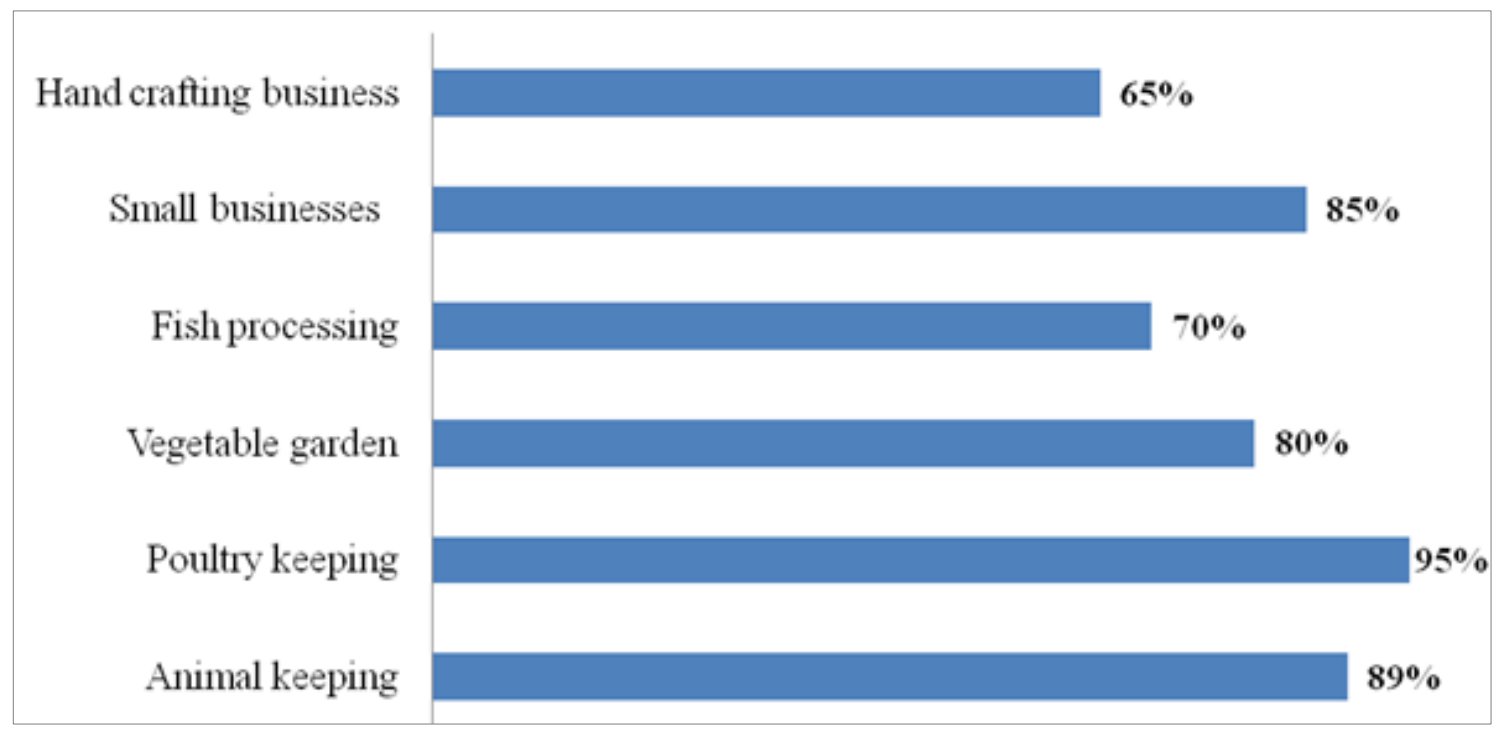

Source: Field data, (2019).

Figure 1. Community based income-generating projects in the study area 
The revealed study findings which are presented in the Figure 1 above contain the 6 major community based income-generating activities in the study as a result of adoption of transformation leadership practices in the area. From the study findings presented in Figure 1 above, the revealed major 6 community based income-generating activities namely animal keeping, poultry keeping, vegetable garden, fish processing, small businesses and hand crafting business. The study findings shows poultry keeping as the mostly practiced activity by $95 \%$ followed by $89 \%$ of animal keeping, as well as small businesses which was practiced by $85 \%$ and vegetable garden which was practiced by $80 \%$. Fish processing was practiced $70 \%$ and hand crafting business $65 \%$ were revealed to be practiced by majority of the study respondents who were the representatives of the communities living in the study area.

Since the examined activities were widely meant for income generation which could be a reliable source of livelihoods for the surrounding communities in the study area such that existence of transformational leadership practices in place namely motivation, periodic appraisals, inspiration, volunteering, mentoring, sharing and training practices. The namely practices which are widely done by the communities in place could rapidly transform their livelihoods such that more members of the community could feel more contained in the livelihoods strategies in the study area as a matter of fact that the practiced activities could provide assurance for the community survival.

\subsection{The Impacts of Transformational Leadership on Innovative Pro-poor Development Initiatives in the Urban West Region}

In the course of attempting the basic questions posed by this study, the study sought to assess the impacts of transformational leadership on innovative pro-poor development initiatives in the Urban West Region. The fact that transformational leadership widely opines the view that behaviors of leaders can be described and evaluated, transformational leaders are widely posited to exhibit charisma and shared vision with their followers, stimulating others to produce exceptional work in any given work environment. Transformational leaders inspire followers to accomplish more by concentrating on the follower's values and helping the follower align these values with the values of the organization. Transformational leadership has been associated with the personal outcomes hence making it an impact-oriented form of leadership in our times (Bass et al., 1995; Adair, 1988). Based on the study findings the impacts of transformational leadership on innovative pro-poor development initiatives in the Urban West Region are presented in the Figure 2 below.

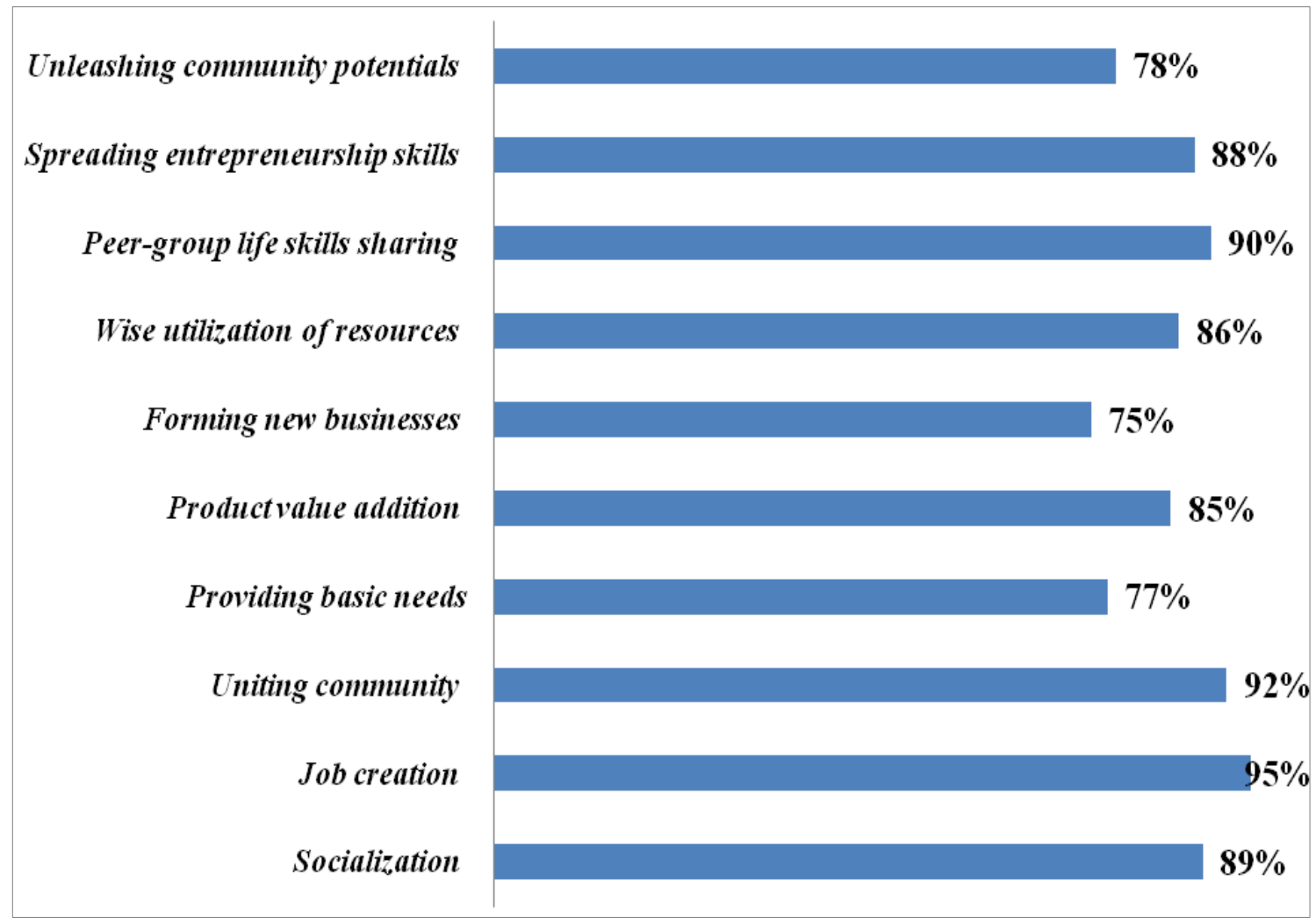

Source: Field data, (2019)

Figure 2. Impacts of transformational leadership on innovative pro-poor development initiatives in the Urban West Region 
The study findings revealed 10 major impacts of transformational leadership on innovative pro-poor development initiatives in the Urban West Region namely socialization $89 \%$, job creation $95 \%$, uniting community $92 \%$, providing basic needs $77 \%$, product value addition $85 \%$, forming new businesses $75 \%$, wise utilization of resources $86 \%$, peer-group life skills sharing 90\%, spreading entrepreneurship skills $88 \%$ and unleashing community potentials responded by $78 \%$. The fact that transformational leaders are those leaders who generally observe principles of human dignity and worth, human rights, good social values and individual and socio-political transformation; such leaders are able to recognize and enhance existing needs or demands of current community the impacts must be realistic as it is widely suggested by Burns (1978). The examined impacts are obvious due to the fact that leadership style in an organization is one of the factors that play significant role in enhancing or retarding the interest and commitment of the individuals in any community hence being the major reason for all forms of managers to select transformational leadership more that any form of leadership (Glantz, 2002).

The revealed highly significant impacts of transformational leadership namely job creation 95\%, uniting community $92 \%$ and peer-group life skills sharing $90 \%$ are envisaged to widely contribute to the existing innovative pro-poor development initiatives in the Urban West Region since the majority of the revealed income generating activities are done in various groups of women and youth. The findings are in line with Mathafena (2007) findings which posit transformational leaders as leaders who understand their moral responsibility as that of contributing to the transformation and enhancement of individuals and communities for a higher communal good. Mathafena (2007) further opine that in transformational leadership leaders behave in ways that motivate and inspire those around them by providing meaning and challenge since it embrace teamwork spirit, enthusiasm and optimism are displayed in the community development. The fact that transformational leadership is termed to be more effective than transactional leadership make it worth revealed the actual role played by transformational leadership towards enhancing community development.

Following the posited fact by the study findings, the transformational leadership outcomes have changed the lives of many people ranging from income generating role to community development role. These among other things were featured in one interview from Matarumbeta shehia positing:

"Transformational leadership has been a form of leadership which suits today's complex environment in all community aspects such that the leaders play a very important role to lead their followers to fulfill individuals and community towards achieving goals effectively. By communicating with their community members in all areas and getting them involved result to a remarkable change. The introduced community based income generating projects have made many people's lives changed including widows, widowers, drug addicts. When making the marginalized societies participate make them employ themselves in the near future as they are all trained and practice thoroughly and to arrange manpower, finance and marketing wisely. Indeed a leader must have an honest understanding of who you are, what you know, and what you can do, for what we have seen in the recent leadership practices in our area reveal the actual contribution of transformation leadership to be successful. For the lives of people changed, transformation leadership proved to be the system worthy of being followed for the sake of development initiatives and since the system bases on innovation and discovery is envisaged to work more effectively in bring people's lives into the meaning of these modern times.",

The prevailing practiced leadership practices have revealed to result into various impacts. The fact that leaders also have to build up cohesiveness within the organization, they kept carrying out leadership processes by applying their leadership knowledge and skills to the community of their followers. Since Lefton et al., (2000) further opined leaders as people "who provide vision and meaning for an institution and embodies the ideals toward which the community development, good leaders develop through a never ending process of self-study, education, training, and experience.

\subsection{Challenges Facing the Adoption of Transformational Leadership in Various Development Initiatives in the Urban West Region}

The study sought to reveal the challenges facing the adoption of transformational leadership in various development initiatives in the Urban West Region. Following the various theoretical reviews, empirical reviews and conceptual frameworks in relation to the problem on hand trying to shed more light on the whole adoption process of transformational leadership among various segments of the community. The fact that the information about usefulness of transformational leadership towards enhancing pro-poor development processes fall short of the challenges facing the adoption of transformational leadership in various development initiatives, this study based on the Urban West Region where the said challenges were drawn. The study findings contained in the Table 6 below shows challenges facing the entire process of adopting transformational leadership in various development initiatives in the Urban West Region. 
Table 6. Challenges facing the adoption of transformational leadership in various development initiatives in the Urban West Region

\begin{tabular}{|l|c|c|}
\hline Challenges & f & \% \\
\hline Lack of skills & 51 & $28 \%$ \\
\hline Lack of fund & 23 & $13 \%$ \\
\hline Lack of knowledge & 20 & $11 \%$ \\
\hline Low level of education & 40 & $22 \%$ \\
\hline Poor perception of the community & 19 & $11 \%$ \\
\hline $\begin{array}{l}\text { Inadequate awareness of the existing pro-poor } \\
\text { projects }\end{array}$ & 27 & $15 \%$ \\
\hline Total & $\mathbf{1 8 0}$ & $\mathbf{1 0 0 . 0}$ \\
\hline
\end{tabular}

Source: Field data (2019).

The revealed challenges facing the adoption of transformational leadership in various development initiatives in the Urban West Region include lack of skills, lack of fund, lack of knowledge, low level of education, poor perception of the community and inadequate awareness of the existing pro-poor projects. The major challenge facing adoption of transformational leadership in various development initiatives in the Urban West Region was lack of skills where by $28 \%$ of all respondents involved in this study mentioned lack of skills as one of the major challenge hindering the adoption of transformational leadership in the on-going pro-poor initiatives in the study area.

Lack of skills among various actors in the development process has made the adoption process of mainstreaming transformational leadership in various development practices. This has been the matter of fact in the ever growing developments in the business world which have also motivated efforts by practitioners and scholars to identify factors that can stimulate organizations performance. Leadership being one of the prominent issue drawn by researchers since old times as one of the major factors that widely influence organizational performance in all forms of communities (Bryman, 1992; Amabile, 1998; Jung, 2001). In these modern times

It is because of their unique traits, transformation leaders are believed to directly and widely influence the organizations and societies overall. On the other hand effective leadership always plays an important role in the growth and better performance of the organization as well as economic development of the particular community, organizations however transformational leaders could be a competitive advantage to increase the efficacy and performance of such organizations.

\section{Conclusions}

This research attempted to reveal the role of transformational leadership on innovative pro-poor development initiatives in Zanzibar where selected community-based income generating projects in the Urban
West Region, Zanzibar were used a case study. Based on the study findings it is hereby concluded:

i. The study concludes male being widely engaged in various development initiatives. Also it was concluded that majority of the available population in the study area composing the community workforce. This was due to the fact that the study involves the total of 180 respondents where by 30 respondents were randomly sampled from each of the six shehias namely Mwera, Kihinani, Kisauni, Kiembesamaki, Matarumbeta and Chumbuni. Majority 114(63.3\%) of the study respondents were male respondents which vividly shows that male are widely engaged in various development initiatives. Also majority of the respondents were found to be in the working age such that they widely contribute to the total workforce available in the particular community.

ii. The study concluded the existence of transformational leadership practices in the study area including motivation, periodic appraisals, inspiration, volunteering, mentoring, sharing and training. On the other hand the study concluded 6 major community based income-generating activities namely animal keeping, poultry keeping, vegetable garden, fish processing, small businesses and hand crafting business. The study findings concluded poultry keeping as the mostly practiced activity in the study area whereby $95 \%$ of the respondents participate in chicken project.

iii. It was further concluded 10 major impacts of transformational leadership on innovative pro-poor development initiatives in the Urban West Region where the major impact such as job creation (95\%) and uniting community (92\%) were the highly responded impacts of transformational leadership on innovative pro-poor development initiatives in the study area.

iv. Based on the revealed study findings, the following challenges were concluded; lack of skills to undertake the projects, lack of fund for establishing the selected pro-poor projects in the study area, lack of knowledge of how to undertaking the selected pro-poor projects in the study area, low level of education of the stakeholders, poor perception of the community and inadequate awareness of the existing pro-poor projects in the study area. Based on the study findings, it is hereby concluded that the major challenges which mainly affect the adoption of transformational leadership in various development initiatives in the Urban West Region include lack of skills among stakeholders in the study area. This is due to the fact that $28 \%$ of all respondents involved in this study mentioned lack of skills among participants as one of the major challenge hindering the adoption of transformational leadership in the on-going pro-poor initiatives in the study area. 


\section{Acknowledgements}

This study has been accomplished by the dedicated efforts of the people of the Urban West region, in Zanzibar. Their support and cooperation rendered to me in the course of realizing this study and in my daily routine duties is incredible. Indeed, I appreciate the people of Urban West region, in Zanzibar where I have been practicing transformational leadership for years now. Lastly but not the least my thanks should go to my lovely wife and children whom their patience and endurance made me work tirelessly to get my studies done on time.

\section{REFERENCES}

[1] Adair, J. (1988). Effective Leadership: A Modern Guide to Developing Leadership Skills London, Pan Books.

[2] Adair, J. (2005). How to grow leaders: The seven key principles of effective leadership development. Sterling, VA: Kogan Page.

[3] Allix, N. (2000). Transformational Leadership Educational Management and Administration Vol 28(1); 7-20 pp.

[4] Bass, B.M. (1985). Leadership and Performance beyond Expectations New York. The Free Press

[5] Bass, B. M. (1990). From transactional to transformational leadership: Learning to share the vision. Organizational Dynamics, New York: Free Press.

[6] Bass, B., and Avolio, B. (1995). Full range leadership development: Manual for the multifactor leadership questionnaire. Menlo Park, CA: Mind Garden.

[7] Bass, B., and Riggio, R. (2006). Transformational leadership. New York, NY: Taylor and Francis.

[8] Burns, J.M. (1978). Leadership, Harper and Row, New York.

[9] Bryman, A (1992). Charisma and Leadership in Organisations London, Sage.

[10] Bryman, A. and Bell, E. (2011). Business Research Methods $3^{\text {rd }}$ Ed. Oxford University Press Inc, New York, 765pp.

[11] Gronn, P. (1996). From Transactions to Transformations: A New World Order in the Study of Leadership. Educational Management and Administration 24 (1) p7-30.
[12] Kouzes, J. M and Posner, B. Z. (2002). The leadership challenge. San Francisco, CA: John Wiley and Sons.

[13] Kouzes, J. M and Posner, B. Z. (2003). The five practices of exemplary leadership. New Jersey, USA: Pfeiffer Wiley Publishers.

[14] Leithwood, K. (1994). Leadership for School Restructuring Educational Administration Quarterly 30(4); 498-518 pp.

[15] Leithwood, K. and Aitken, R. (1995). Making Schools Smarter Newbury Park CA, Corwin Press.

[16] Leithwood, K. and Steinbach, R. (1995). Expert Problem Solving Albany, New York. Sunny Press.

[17] Leithwood, K and Jantzi, D. (1999). Transformational School Leadership Effects: A Replication School Effectiveness and School Improvement Vol 10, No4, 451-479 pp.

[18] Leithwood, K, Jantzi, D and Steinbach, R. (1999). Changing Leadership for Changing Times London, Open University Press.

[19] Lefton, E.R and Victor R. Buzzotta, (2004). Leadership through People Skills, Tata McGraw Publishing Companies Limited, New Delhi.

[20] Maxwell, J. C. (2007). The 21 irrefutable laws of leadership. Nashville, TN: Thomas Nelson.

[21] Obiwuru, T. C., Okwu, A. T., Akpa, V. O and Nwankwere, I. A. (2011). Effects of leadership style on organisational performance: A survey of selected small scale enterprises in Ikosi-Ketu council development area of Lagos State, Nigeria. Australian Journal of Business and Management Research, 1(7), 100-111pp.

[22] Storey, J. (2010). Leadership in organization: Current Issues and Key Trends. Routlege: Hoboken.

[23] United Republic of Tanzania (2010). Tanzania Demographic and Health Survey. Government Printers, Dar es Salaam, Tanzania. $18 \mathrm{pp}$

[24] United Republic of Tanzania (2013). National Population Census 2012. National Bureau of Statistics, Dar es Salaam, Tanzania. 133pp.

[25] Yanmarino, F.J. Dubinsky, A.J. and Spangler, W.D. (1998) Transformational and contingent Reward Leadership: Individual and Group Levels of Analysis. The Leadership Quarterly 9 (1); 27-54 pp

[26] Yuki, G (1994). Leadership in Organizations $3^{\text {rd }}$ Ed Englewood Cliffs, N.J. Prentice-Hall 